\title{
Erratum to: Mortgage-equity release: the potential of housing wealth for future Dutch retirees
}

\author{
Janneke Toussaint $\cdot$ Marja Elsinga
}

Published online: 13 September 2012

(C) Springer Science+Business Media B.V. 2012

\section{Erratum to: J Hous and the Built Environ DOI 10.1007/s10901-012-9301-x}

In the original publication, Prof. Dr. Ir. Marja Elsinga name has been missed out to include in the author group.

The editor apologizes for any confusion this may have caused.

The online version of the original article can be found under doi:10.1007/s10901-012-9301-x.

J. Toussaint $(\bowtie)$

Schuttersveld 9, 2611 WE Delft, The Netherlands

e-mail: Janneke.toussaint@gmail.com

M. Elsinga

OTB Research Institute for the Built Environment, TU Delft, Jaffalaan 9, 2628 BX Delft,

The Netherlands

e-mail: m.g.elsinga@tudelft.nl

URL: www.otb.tudelft.nl

M. Elsinga

OTB Research Institute for the Built Environment, TU Delft, Postbox 5030, 2600 GA Delft, The Netherlands 